\title{
THE PRINCIPLE OF PROPORTIONALITY IN THE JURISPRUDENCE OF THE EUROPEAN COURT OF HUMAN RIGHTS
}

\author{
Kristina Trykhlib, PhD, Assistant Professor \\ Yaroslav Mudryi National Law University \\ Pushkinska str. 77, 61024 Kharkiv, Ukraine, \\ kristina.trihleb3105@ukr.net
}

\section{ABSTRACT}

Some of the rights enshrined in the ECHR are absolute (the prohibition of torture (Article 3), the prohibition of slavery and forced labor (Article 4)). It means that they can under no circumstances be restricted or reduced.

All other rights may be partially restricted under the terms of Art. 15 of the ECHR, in cases of social urgency - martial / emergency within the limits necessary to prevent the threat to the life of the nation. Some ECHR articles explicitly state the conditions for restrictions on human rights and freedoms. So, the right to privacy (Art. 8), freedom of thought, conscience and religion (Art. 9), freedom of expression (Art. 10) and freedom of assembly (Art. 11) may be restricted, if required by the law and is necessary in a democratic society.

Thus, conventional rights may also have inherent limitations. In particular, in some cases, the rights guaranteed by the various articles of the ECHR collide.

Therefore, the main objective of this paper is to research the essence and core elements of the principle of proportionality in the jurisprudence of the ECtHR.

To evaluate the proportionality of an interference with a right or freedom, it is necessary to determine its impact on the law, the causes of the interference, its results, the importance of local circumstances, and the complexity of objective evaluation of relevant rights and interests. It is the states that must justify such intervention. Herewith, the reasons should be 'substantial and sufficient', the need for the restriction 'established by the law', the exceptions 'clearly stated', and the interference must comply with 'urgent social need'.

According to the principle of proportionality, all legal actions and state decisions must be established by the law, necessary, relevant (suitable) and least restricts the right of the individual. In addition, the proportionality test must ensure that a person's loss from the restriction of the right is commensurate with the benefit from the aim pursued. The balance is fair, if the restriction does not encroach on the very essence of the right and does not cause its real content to be lost. 
In assessing the proportionality of a state's interference, the ECtHR applies the doctrine of the margin of appreciation, which can be broad or narrow.

Thus, the principle of proportionality, which is closely linked to the principle of effective protection, significantly influences the case law of the ECtHR. Most of the disputes over proportionality arise in the context of human rights restrictions guaranteed by Articles 8 (2) - 11 (2) of the ECHR.

Therefore, the principle of proportionality requires national public authorities to strike a fair balance between competing public and private interests at stake. The ECtHR assesses such factors, as the importance of competing interests, objectivity (adequacy, reasonableness) of the restriction, the existence of consensus among Council of Europe member States on the issue under consideration.

Keywords: European Court of Human Rights, limitations on human rights, democratic necessity test, principle of proportionality, margin of appreciation, consensus

\section{INTRODUCTION}

The principle of proportionality is extremely important for the effective protection of human rights in practice, as it concerns any interference with or restriction of human rights, primarily, by a state. This principle follows that any action by a state that in one way or another affects human rights must be necessary, expedient (appropriate), and reasonably justified by a state in each case. Thus, the principle of proportionality imposes a positive obligation on public authorities to prove the need for their actions, which restrict human rights. Therefore, any actions or measures that a state takes to achieve its legitimate aim and which interfere in some way with human rights and freedoms must pass the so-called proportionality test, which was originally developed in the German legal doctrine1.

On the other hand, the principle of proportionality is an integral tool of a judge, who, when resolving a dispute, usually deals with various human rights, as well as interests, including private and public ones, which come into conflict. In such cases, in order to strike a fair balance, a judge weighs these rights and interests and, ultimately, gives priority to one of them. In any case, a court decision must be reasonable and fair. In this context I bear in mind neither formal justice, which can be essentially understood as equality before the law and the court, nor procedural justice (fairness regarding outcomes), but, prima facie, material (substantive) justice that concerns the justice or injustice of the content of rules or laws. So, it is substantive justice that is manifested in the principle of proportionality (such as, for example, the proportionality of the gravity of the offense and the specific type and measure of legal liability for its commission).

Möller, K., Proportionality: Challenging the critics, International Journal of Constitutional Law, vol. 10, issue 3, 2012, pp. $709-731$ 
Consequently, in seeking to achieve a fair balance, a court always balances between different rights and issues at stake. Of course, one can argue about the existence of objective justice and truth, but nonetheless in every case the main task of a court is to find the solution to the issue that would be justified in terms of the optimal balance of various human rights and interests in modern society, which is developing dynamically and requires constant updating of approaches, including law enforcement. Thereby, the principle of proportionality underlies the application of law, whose main ultimate goal is to protect human rights.

Based on the foregoing, it can be noted that the principle of proportionality is multidimensional. Moreover, it is a general principle of law ('optimization requirement'2) that includes key ideas of law (prima facie requirements3). However, the application of the principle of proportionality is not always so obvious. It depends on many factors. First and foremost, the interpretation and argumentation of the court depends on the specific type of human rights and interests at stake, and also, if we study the jurisprudence of the European Court of Human Rights (hereinafter: ECtHR), on the presence or absence of consensus among the member states of the Council of Europe regarding the issue under consideration. This involves the so-called doctrine of the margin of appreciation (free discretion) of a state, which can be wide or narrow. According to it, the ECtHR gives priority to the state's assessment, interpretation of certain events, facts, actions, situations and any other phenomena within its own jurisdiction4. The width of the margin depends on the interests at stake, the context of the interference, the impact of a possible consensus in such matters, the aim pursued by the interference, the degree of proportionality of it, etc. 5 The doctrine is further of practical importance in the context of the interpretation of the permissible limitations on human rights6.

\section{PERMISSIBLE LIMITATIONS ON HUMAN RIGHTS}

Under the European Convention on Human Rights (hereinafter: ECHR) any specific interference with human rights is permissible only if it is necessary in pursuit

Alexy, R., Constitutional Rights, Balancing and Rationality, Ratio Juris, vol. 16, 2003, pp. 131 - 140

Alexy, R., Formal principles: Some replies to critics, International Journal of Constitutional Law, vol. 12, issue 3, 2014, pp. $511-524$

4 Judgment Handyside v. the United Kingdom (1976), Application no. 5493/72, par. 48, 49, [http:// hudoc.echr.coe.int/eng?i=001-57499], accessed 20. March 2020

5 Spielmann, D., Allowing the Right Margin the European Court of Human Rights and the National Margin of Appreciation Doctrine: Waiver or Subsidiarity of European Review?, Cambridge Yearbook of European Legal Studies, vol.. 14, 2012, pp. $381-418$

6 McGoldrick, D., A defence of the margin of appreciation and an argument for its application by the Human Rights Committee, International and Comparative Law Quarterly, vol. 65, issue 1, 2016, pp. 21 - 60 
of one of the legitimate aims listed in the ECHR7. The degree of such interference depends on the specific right. Therefore, absolute human rights (prohibition of torture, slavery and forced labor) cannot be limited. When it comes to the fundamental and non-derogable right to life (Art. 2)8, the grounds for the interference are significantly limited. In particular, according to Article 2 of the ECHR, any deprivation of life may be justified as a result of the use of force, if it is absolutely necessary and only on the exhaustive grounds, namely: in defence of any person from unlawful violence; in order to effect a lawful arrest or to prevent the escape of a person lawfully detained; in action lawfully taken for the purpose of quelling a riot or insurrection.9

Other rights and freedoms (non-absolute, qualified human rights), such as the right to respect for private and family life (Art. 8), freedom of thought, conscience and religion (Art. 9), freedom of expression (Art. 10), freedom of assembly and association (Art. 11) may be restricted in accordance with the law when it is necessary in a democratic society in the interests of national security, public safety or the economic well-being of the country, for the prevention of disorder or crime, for the protection of health or morals, or for the protection of the rights and freedoms of others. 10

Moreover, Article 10 of the ECHR enshrines along with the restrictions already listed, such additional grounds for restrictions, as the interest of territorial integrity, the prevention of disclosure of information received in confidence, as well as the maintenance of the authority and the impartiality of the judiciary. 11

In addition, Art. 15 de facto allows countries to derogate from their convention obligations in the event of war or other public emergency threatening the life of the nation to the extent strictly required by the exigencies of the situation, and in consistence with their other obligations under international law.12 In this case, international humanitarian law comes into force.

Thereby, the question arises as to the criteria according to which these restrictions should be determined and applied in practice, since the analysis of the fixed restrictions shows that their meaning and, accordingly, interpretation may vary due

Article $18 \mathrm{ECHR}$

8 Judgment McCann and Others v. the United Kingdom (1995), Application no. 18984/91, par. 147, [http://hudoc.echr.coe.int/eng?i=001-57943], accessed 20. March 2020

$9 \quad$ Article 2 par. 2 ECHR

10 Articles 8-11 ECHR

11 Article 10 ECHR

12 Article $15 \mathrm{ECHR}$ 
to numerous factors. And it is the ECtHR in its jurisprudence that clarifies the very essence and content of these restrictions.

In the present paper, I would like to concentrate on such vague concepts, as 'prescribed by law' and 'necessity in a democratic society', which requires an assessment of their proportionality and, thus, directly depend on the margin of appreciation afforded to a state.

\section{1. 'Legal' interference with human rights and freedoms}

As stated above, any interference with or restriction of human rights must be in accordance with the law' or 'prescribed by law'.13 In its jurisprudence the ECtHR provides explanation of such 'legal' interference with specific human rights and freedoms. In particular, in the case of Huvig $v$. France (1990) it points out that "the expression 'in accordance with the law', within the meaning of Article $8 \$ 2$ (art. 8-2), requires firstly that the impugned measure should have some basis in domestic law; it also refers to the quality of the law in question, requiring that it should be accessible to the person concerned, who must moreover be able to foresee its consequences for him, and compatible with the rule of law".14 The ECtHR further underlines that the consequences need not be foreseeable with absolute certainty, since "it may bring in its train excessive rigidity and the law must be able to keep pace with changing circumstances. Accordingly, many laws are inevitably couched in terms which, to a greater or lesser extent, are vague and whose interpretation and application are questions of practice". 15 The degree of precision required of the 'law' depends on the particular subject-matter.16

The ECtHR "has always understood the term 'law' in its 'substantive' sense, not its 'formal' one; it has included both enactments of lower rank than statutes ... and unwritten law. ...In a sphere covered by the written law, the 'law' is the enactment in force as the competent courts have interpreted it in the light, if necessary, of any new practical developments".17

\footnotetext{
13 Articles 8-11 ECHR

14 Judgment Huvig v. France (1990), Application no. 11105/84, par. 26, [http://hudoc.echr.coe.int/ eng? $\mathrm{i}=001-57627]$, accessed 20. March 2020

15 Judgment The Sunday Times $v$. the United Kingdom (1979), Application no. 6538/74, par. 49, [http:// hudoc.echr.coe.int/eng?i=001-57584], accessed 20. March 2020

16 Judgment Malone v. the United Kingdom (1984), Application no. 8691/79, par. 68, [http://hudoc.echr. coe.int/eng?i=001-57533], accessed 20. March 2020

17 Judgment Kruslin v. France (1990), Application no. 11801/85, par. 29, [http://hudoc.echr.coe.int/ eng?i=001-57626], accessed 20. March 2020
} 
Indeed, the law must "indicate with reasonable clarity the scope and manner of exercise of the relevant discretion conferred on the public authorities" in order to provide the enjoyment of the minimum degree of protection of the citizens under the rule of law in a democratic society, 18 while respecting the legitimate aim of such measure, that would give the individual adequate protection against arbitrary interference.19 On the other hand, the detailed procedures and conditions to be observed do not necessarily have to be incorporated in rules of substantive law.20 It may be enshrined in the secondary law (delegated or subordinate legislation, which is created by ministers or other bodies, e.g., decrees, orders, decisions, instructions, directives, regulations, etc.).

Thus, the 'accessibility' requires the law to be brought to the public attention, that is, the public proclamation (promulgation) of laws and their publication, with a view to familiarize individuals with their content and, subsequently, the possibility to foresee the consequences in case of application of a certain law.

Regarding the requirement of the law's 'foreseeability' as to the meaning, nature and the scope of the applicable measures, the ECtHR emphasizes that "the phrase 'in accordance with the law' does not merely refer back to domestic law but also relates to the quality of the law, requiring it to be compatible with the rule of law, which is expressly mentioned in the preamble to the Convention..."21 For instance, concerning the right to respect for private and family life (Art. 8), there must be a measure of legal protection in national law against arbitrary interferences by public authorities, especially where executive power is exercised in secret. In any case, the law must be sufficiently clear in its terms to give individuals an adequate indication as to the circumstances and the conditions on which public authorities are empowered to interfere with the rights. 22

The scope of the 'foreseeability' and 'accessibility' depends on the content of the instrument in issue, the sphere of regulation, the number and status of those to whom it is addressed. 23

\footnotetext{
18 Judgment Huvig v. France (1990), op. cit., note 6, par. 35

19 Judgment Malone v. the United Kingdom (1984), op. cit., note 8, par. 68

20 Judgment Silver and Others $v$. the United Kingdom (1983), Application no. 5947/72; 6205/73; 7052/75; 7061/75; 7107/75; 7113/75; 7136/75, par. 88, [http://hudoc.echr.coe.int/eng?i=001-57577], accessed 20. March 2020

21 Judgment Malone v. the United Kingdom (1984), op. cit., note 8, par. 67

22 Judgment Kruslin v. France (1990), op. cit., note 9, par. 29

23 Judgment Groppera Radio AG and Others v. Switzerland (1990), Application no. 10890/84, par. 68, [http://hudoc.echr.coe.int/eng?i=001-57623], accessed 20. March 2020
} 


\subsection{Democratic necessity test}

Since any interference with human rights (in particular, with rights guaranteed by Articles 8-11 of the ECHR) must be 'necessary in a democratic society', it is advisable to define this concept. Moreover, the ECtHR in its practice has developed certain criteria for assessing such necessity, - the so-called democratic necessity test.

It is extremely difficult to test the persuasiveness of any defence position of a state, so, the main objective of this test is to "ensure that it complies with the genuine interests of democracy and is not merely political expediency in disguise". 24

The ECtHR highlights that "not only is political democracy a fundamental feature of the European public order but the Convention was designed to promote and maintain the ideals and values of a democratic society. ... By virtue of the wording of the second paragraph of Article 11, and likewise of Articles 8, 9 and 10 of the Convention, the only necessity capable of justifying an interference with any of the rights enshrined in those Articles is one that may claim to spring from 'democratic society'..." 25 In its practice, the ECtHR refers to such basic elements of a 'democratic society', as pluralism, tolerance and broadmindedness. It also points out that "democracy does not simply mean that the views of the majority must always prevail: a balance must be achieved which ensures the fair and proper treatment of minorities and avoids any abuse of a dominant position..."26

Based on the case law of the ECtHR, the so-called absolute (strict) necessity test and the persuasive (general) test on necessity ('the convincing necessity') can be distinguished. Herewith, the application of a certain approach depends on the specific type of human rights. Thus, when it comes to the deprivation of life, the democratic necessity test is very strict. In turn, by referring to the rights guaranteed in Articles $8-11$, the persuasive test on necessity must be applied.

\subsubsection{Standard of 'absolute necessity'}

As stated the ECtHR, the term 'deprivation of life' "indicates that a stricter and more compelling test of necessity must be employed by the Court, if compared with that normally applicable when determining whether State action is 'necessary in a democratic society' under paragraphs 2 of Articles 8 to 11 of the Convention.

\footnotetext{
24 Greer, S., The exceptions to Articles 8 to 11 of the European Convention on Human Rights, Council of Europe Publishing, Strasbourg, 1997, p. 14

25 Judgment Gorzelik and Others v. Poland (2004), Application no. 44158/98, par. 89, [http://hudoc. echr.coe.int/eng?i=001-61637], accessed 20. March 2020

26 Ibid., par. 90
} 
Consequently, the force used must be strictly proportionate to the achievement of the permitted aims..."27

Moreover, the ECtHR points out that "any use of force must be no more than 'absolutely necessary' for the achievement of one or more of the purposes set out in sub-paragraphs (a) to (c).... The authorities must take appropriate care to ensure that any risk to life is minimised. The Court must also examine whether the authorities were not negligent in their choice of action. ... The same applies to an attack where the victim survives but which, because of the lethal force used, amounted to attempted murder..."28

In this, "the circumstances in which deprivation of life may be justified must be strictly construed. ... In particular, the Court has held that the opening of fire should, whenever possible, be preceded by warning shots... The use of force by agents of the State in pursuit of one of the aims delineated in paragraph 2 of Article 2 of the Convention may be justified under this provision where it is based on an honest belief which is perceived, for good reasons, to be valid at the time but which subsequently turns out to be mistaken. To hold otherwise would be to impose an unrealistic burden on the State and its law-enforcement personnel in the execution of their duty, perhaps to the detriment of their lives and those of others..."29

Effective respect for human rights requires that policing operations be sufficiently regulated by national legislation, the existence of a system of adequate and effective safeguards against arbitrariness and abuse of force, even against avoidable accident.30 "Members of the security forces should not be left in a vacuum when performing their duties, whether in the context of a prepared operation or a spontaneous chase of a person perceived to be dangerous: a legal and administrative framework should define the limited circumstances in which law-enforcement officials may use force and firearms, in the light of the international standards which have been developed in this respect. ... In particular, law enforcement agents must be trained to assess whether or not there is an absolute necessity to use firearms, not only on the basis of the letter of the relevant regulations, but also with due regard to the pre-eminence of respect for human life as a fundamental value..."31

\footnotetext{
27 Judgment Finogenov and Others v. Russia (2012), Application nos. 18299/03 and 27311/03, par. 210, [http://hudoc.echr.coe.int/eng?i=001-108231], accessed 20. March 2020

28 Judgment Isayeva, Yusupova and Bazayeva v. Russia (2005), Application nos. 57947/00, 57948/00 and 57949/00, par. 169, 171, [http://hudoc.echr.coe.int/eng?i=001-68379], accessed 20. March 2020

29 Judgment Giuliani and Gaggio v. Italy (2011), Application no 23458/02, par. 177, 178, [http://hudoc. echr.coe.int/eng?i=001-104098], accessed 20. March 2020

$30 \quad$ Ibid., par. 162

31 Ibid., par. 162, 163
} 
Hence, the ECtHR emphasizes that when lethal force is used by a state, it must take into consideration and assess various aspects, such as the actions of the agents of a state who actually administered the force, all the surrounding circumstances, including the relevant legal or regulatory framework in place, the planning and control of the actions under examination. 32

Nevertheless, the ECtHR may occasionally depart from the standard of 'absolute necessity', particularly, in cases where certain aspects of the situation lie far beyond its expertise, where the national authorities had to act under tremendous time pressure, and where their control of the situation was minimal.33 Meanwhile, "the more predictable a hazard, the greater the obligation to protect against it".34

\subsubsection{Persuasive (convincing) test on necessity}

Regarding the rights guaranteed by Articles $8-11$ of the ECHR, the necessity test is persuasive. In particular, the ECtHR stresses that the freedom of expression "constitutes one of the essential foundations of a democratic society; subject to paragraph 2 of Article 10 (art. 10-2), it is applicable not only to 'information' or 'ideas' that are favourably received or regarded as inoffensive or as a matter of indifference, but also to those that offend, shock or disturb. Freedom of expression, as enshrined in Article 10 (art. 10), is subject to a number of exceptions which, however, must be narrowly interpreted and the necessity for any restrictions must be convincingly established" 35 .

Following the practice of the ECtHR, the convincing necessity test requires establishing the existence of a 'pressing social need' and 'relevant and sufficient' reasons for interference with human rights and freedoms enshrined in Articles $8-11$. Such interference also must be 'proportionate to the legitimate aim' pursued by public authorities.36

Thus, in the case of The Sunday Times v. the United Kingdom (no. 2) the ECtHR explained that "the adjective 'necessary', within the meaning of Article 10 para. 2 (art. 10-2), implies the existence of a 'pressing social need'. The Contracting States

\footnotetext{
$32 \quad$ Ibid., par. 164

33 Ibid., par. 211

34 Judgment Kavaklioğlu and Others v. Turkey (2016), Application no. 15397/02, par. 176, [http://hudoc. echr.coe.int/eng?i=001-157821], accessed 20. March 2020

35 Judgment Observer and Guardian v. the United Kingdom (1991), Application no. 13585/88, par. 59 (a), [http://hudoc.echr.coe.int/eng?i=001-57705], accessed 20. March 2020

36 Judgment National Federation of Sportspersons' Associations and Unions (FNASS) and Others v. France (2018), Application nos. 48151/11 and 77769/13, par. 167, [http://hudoc.echr.coe.int/ eng?i=001-180442], accessed 20. March 2020
} 
have a certain margin of appreciation in assessing whether such a need exists, but it goes hand in hand with a European supervision, embracing both the law and the decisions applying it, even those given by independent courts. The Court is therefore empowered to give the final ruling on whether a 'restriction' is reconcilable with freedom of expression as protected by Article 10 (art. 10)".37 The main task of the ECtHR is "to look at the interference complained of in the light of the case as a whole and determine whether it was 'proportionate to the legitimate aim pursued' and whether the reasons adduced by the national authorities to justify it are 'relevant and sufficient'".38

The ECtHR also emphasizes that the adjective 'necessary', within the meaning of Article 10 (2), is not synonymous with 'indispensable', neither has it the flexibility of such expressions as 'admissible', 'ordinary', 'useful', 'reasonable' or 'desirable', and that it implies the existence of a 'pressing social need'. In this context, the domestic authorities enjoy a wide margin of appreciation.39 The ECtHR stated: "... It is for the national authorities to make the initial assessment of the reality of the pressing social need implied by the notion of 'necessity' in this context". 40

However, despite the established judicial practice of applying this test, its criteria are still quite ambiguous. Therefore, the legal doctrine repeatedly draws attention to the need to improve it. It would be advisable the test for fair balance to be systematically preceded by a means-ends test. 41 The test of means and ends would allow the ECtHR to examine the justification of the reasonableness of the choice of means, which is a substantial element of the reasonableness of an interference with human rights. Its application could also be helpful in terms of avoiding the difficulties related to balancing review. Moreover, if the ECtHR would find that the means or measures chosen by a state were unsuitable or unnecessary, there would be no further need to investigate whether, after all, the national authorities did strike a fair (reasonable) balance. 42

\footnotetext{
37 Judgment The Sunday Times v. the United Kingdom (no. 2) (1991), Application no. 13166/87, par. 50 (c), [http://hudoc.echr.coe.int/eng?i=001-57708], accessed 20. March 2020

$38 \quad$ Ibid., par. 50 (d)

39 Judgment The Sunday Times v. the United Kingdom (1979), op. cit., note 15, par. 59

$40 \quad$ Judgment Handyside v. the United Kingdom (1976), op. cit., note 4, par. 48

41 Gerards, J., How to improve the necessity test of the European Court of Human Rights, International Journal of Constitutional Law, vol. 11, issue 2, 2013, pp. $466-490$

$42 \quad$ Ibid., p. 488
} 


\section{TEST OF PROPORTIONALITY}

According to the principle of proportionality, all legal actions and decisions taken by public authorities must be relevant (suitable), that is the appropriateness of the measure intended to achieve the legitimate aim pursued by public authority. It also includes a ban on using prohibited means, such as torture, and the assessment of the legitimacy of the purpose of taken measure that must derives from the constitution and the laws. Moreover, public authorities must provide sufficient justification for applying a certain measure and its necessity to achieve a specific goal. Hence, the second important requirement for the state actions is the need to apply the measure that least restricts the right of the individual. Finally, the third criterion is the so-called proportionality in the narrow sense, namely the proportionality of the loss incurred by the infringement of the right to the benefit from the goal achieved, - balancing principle (German model)43. At the same time, some scholars note that the ECtHR pays the most attention to the proportionality in the narrow sense. 44

The proportionality test also involves a comparative analysis of the intensity of the intervention with the goal being pursued. In this process the legal and moral values of the society are taken into account, the rights, interests and objectives of the parties are weighed. Based on this, the balance is fair provided that the restriction does not encroach on the very essence of the right and does not lead to the loss of its real content. In this regard, the ECtHR emphasizes: "It must be satisfied that the limitations applied do not restrict or reduce the access left to the individual in such a way or to such an extent that the very essence of the right is impaired".45

Even so, the application of the above requirements causes certain difficulties in practice, since their formulation is quite vague. Therefore, in its case law the ECtHR developed additional criteria to strike a balance between private and public interests, specifically the extent to which both the public authorities and the individual acted in good faith, the foreseeability of the state action and the legitimacy of the individual's expectations.46 Thus, in the case of National Union of Rail, Maritime and Transport Workers v. the United Kingdom (2014), the ECtHR didn't find a violation of Article 11 (freedom of assembly and association) and pointed

43 Alexy, op. cit., note 3, pp. $511-524$

44 Huber, P., M., The principle of Proportionality, in: Schroeder, W. (ed.), Strengthening the rule of law in Europe: from a common concept to mechanisms of implementation, Hart Publishing, Oxford and Portland, Oregon, 2016, pp. $98-112$

45 Judgment Prince Hans-Adam II of Liechtenstein v. Germany (2001), Application no. 42527/98, par. 44, [http://hudoc.echr.coe.int/eng?i=001-59591], accessed 20. March 2020

46 Popelier, P.; Van De Heyning, C., Procedural rationality: giving teeth to the proportionality analysis, European Constitutional Law Review, No. 9 (2), 2013, pp. 230 - 262 
out: "The Government have argued that the 'pressing social need' for maintaining the statutory ban on secondary strikes is to shield the domestic economy from the disruptive effects of such industrial action, which, if permitted, would pose a risk to the country's economic recovery. In the sphere of social and economic policy, which must be taken to include a country's industrial-relations policy, the Court will generally respect the legislature's policy choice unless it is 'manifestly without reasonable foundation'... Moreover, the Court has recognised the 'special weight' to be accorded to the role of the domestic policy-maker in matters of general policy on which opinions within a democratic society may reasonably differ widely... The ban on secondary action has remained intact for over twenty years, notwithstanding two changes of government during that time. This denotes a democratic consensus in support of it, and an acceptance of the reasons for it, which span a broad spectrum of political opinion in the United Kingdom. These considerations lead the Court to conclude that in their assessment of how the broader public interest is best served in their country in the often charged political, social and economic context of industrial relations, the domestic legislative authorities relied on reasons that were both relevant and sufficient for the purposes of Article 11".47 Moreover, it stressed: "As has been recognised in the case-law, it is legitimate for the authorities to be guided by considerations of feasibility, as well as of the practical difficulties - which, for some legislative schemes, may well be large-scale - to which an individuated approach could give rise, such as uncertainty, endless litigation, disproportionate public expenditure to the detriment of the taxpayer and possibly arbitrariness". 48

Nevertheless, despite the well-established criteria for the proportionality test, their implementation ultimately depends on the width of the margin of appreciation granted by the ECtHR to a state. It is the assessment of discretionary powers left to public authorities that plays a core role in verifying the compliance with or violation of the principle of proportionality by domestic authorities.

\section{MARGIN OF APPRECIATION}

The doctrine of the margin of appreciation was elaborated in the case law of the ECtHR. In fact, it is a key tool of the ECtHR that allows it, on the one hand, to impose an autonomous interpretation of conventional rights by the ECtHR on domestic authorities and, on the other hand, to limit its interference with the in-

\footnotetext{
47 Judgment National Union of Rail, Maritime and Transport Workers $v$. the United Kingdom (2014), Application no. 31045/10, par. 99, [http://hudoc.echr.coe.int/eng?i=001-142192], accessed 20. March 2020

48 Ibid., par. 103
} 
terpretation provided by national courts. 49 Accordingly, by granting a state wider or narrower margin of appreciation, the ECtHR takes into consideration the following criteria: 1) the subsidiarity nature of the ECHR. 2) A fair balance between the effective protection and the sovereignty of a state (reasonable distribution of powers between the supranational and national level). In particular, the ECtHR has repeatedly emphasized that domestic authorities are better placed to assess certain elements of the proportionality test and settle a dispute. 3) Diversity of social and political contentions of the 'good society' among different states that affects the balance between individual rights guaranteed by the ECHR and the conception of public good in various contexts and societies. 50

Thereby, the margin allowed will be relatively narrow or significantly restricted where the right at stake is crucial to the individual's effective enjoyment of intimate or key rights and where a particularly important facet of an individual's existence or identity is at stake. The margin will be wider if the case raises sensitive moral or ethical issue. 51

Herewith, some researchers suppose that the 'institutionally sensitive' approach can be applied, in which the legislative bodies will have wider margin of appreciation than the executive ones.52 For instance, in the Hatton and Others $v$. the United Kingdom [GC] judgment (2003), the ECtHR referred to the 'direct democratic legitimation' of legislature and emphasized the subsidiarity nature of the ECHR. It stressed that "the national authorities have direct democratic legitimation and are, as the Court has held on many occasions, in principle better placed than an international court to evaluate local needs and conditions".53

Hence, the width of the margin of appreciation will vary according to the nature of the right in issue, its importance for the individual and the nature of the activities restricted, as well as the nature of the aim pursued by the restrictions. 54

49 Huscroft, G., Proportionality and the Relevance of Interpretation, in: Huscroft, G.; Miller, B. W.; Webber, G.(eds.), Proportionality and the rule of law: Rights, Justification, Reasoning, Cambridge University Press, New York, 2014, pp. 186 - 202

50 Popelier; Van De Heyning, op. cit., note 46, p. 231

51 Judgment Dubská and Krejzová v. the Czech Republic (2016), Application nos. 28859/11 and 28473/12, par. 178, [http://hudoc.echr.coe.int/eng?i=001-168066], accessed 20. March 2020

52 Popelier; Van De Heyning, op. cit., note 46, p. 232

53 Judgment Hatton and Others v. the United Kingdom [GC] (2003), Application no. 36022/97, par. 97, [http://hudoc.echr.coe.int/eng?i=001-61188], accessed 20. March 2020

54 Judgment Chapman v. the United Kingdom (2001), Application no. 27238/95, par. 91, [http://hudoc. echr.coe.int/eng?i=001-59154], accessed 20. March 2020 
Therefore, the width of the margin of appreciation depends on the presence or absence of the European consensus on a particular issue and on the specific type of human rights. In particular, when it comes to absolute rights, the margin is narrow. Moreover, if there is a consensus among member states of the Council of Europe on a particular issue, the margin of appreciation is narrow too, and vice versa. At the same time, if the issue concerns complex moral and ethical issues on which there is no consensus, then the margin of a state's discretion is quite wide.

\subsection{Absolute human rights and right to life}

\subsubsection{Probibition of torture}

In the case of O'Keeffe $v$. Ireland (2014) the ECtHR highlighted that "Article 3 enshrines one of the most fundamental values of democratic society. It prohibits in absolute terms torture or inhuman or degrading treatment or punishment". 55 It imposes positive obligations on a state and requires a state to take all possible and reasonable measures to provide effective protection and "to ensure that individuals within their jurisdiction are not subjected to torture or inhuman or degrading treatment, including such ill-treatment administered by private individuals".56

In addition, Article 3 of the ECHR imposes an obligation on a state not to extradite a person who may be subjected to torture in the requested state. Thus, in the Trabelsi v. Belgium judgment (2015), the applicant complained that his extradition to the United States of America exposed him to treatment incompatible with Article 3. He contended that offences, on the basis of which his extradition had been granted, carried a maximum life prison sentence which was irreducible, and that if he were convicted he would have no prospect of ever being released.57 So, the ECtHR considered that "under well-established case-law, protection against the treatment prohibited under Article 3 is absolute, and as a result the extradition of a person by a Contracting State can raise problems under this provision and therefore engage the responsibility of the State in question under the Convention, where there are serious grounds to believe that if the person is extradited to the requesting country he would run the real risk of being subjected to treatment contrary to Article 3..., the Court reiterates that it is acutely conscious of the difficulties faced by States in protecting their populations against terrorist violence,

\footnotetext{
55 Judgment O'Keeffe v. Ireland (2014), Application no. 35810/09, par. 144, [http://hudoc.echr.coe.int/ eng?i=001-140235], accessed 20. March 2020

56 Ibid.

57 Judgment Trabelsi v. Belgium (2015), Application no. 140/10, par. 116 - 118, [http://hudoc.echr.coe. int/eng?i=001-146372], accessed 20. March 2020
} 
which constitutes, in itself, a grave threat to human rights. It is therefore careful not to underestimate the extent of the danger represented by terrorism and the threat it poses to society... It considers it legitimate, in the face of such a threat, for Contracting States to take a firm stand against those who contribute to terrorist acts (ibid). Lastly, the Court does not lose sight of the fundamental aim of extradition, which is to prevent fugitive offenders from evading justice, nor the beneficial purpose which it pursues for all States in a context where crime is taking on a larger international dimension... However, none of these factors have any effect on the absolute nature of Article 3. As the Court has affirmed on several occasions, this rule brooks no exception". 58

Hence, Article 3 of the ECHR "prohibits in absolute terms torture or inhuman or degrading treatment or punishment, irrespective of the circumstances and the victim's behaviour".59

\subsubsection{Right to life}

In the case of Isayeva, Yusupova and Bazayeva v. Russia (2005) the ECtHR points out that "Article 2, which safeguards the right to life and sets out the circumstances where deprivation of life may be justified, ranks as one of the most fundamental provisions in the Convention, from which in peacetime no derogation is permitted under Article 15. Together with Article 3, it also enshrines one of the basic values of the democratic societies making up the Council of Europe. ... The Court is sensitive to the subsidiary nature of its role and recognises that it must be cautious in taking on the role of a first instance tribunal of fact, where this is not rendered unavoidable by the circumstances of a particular case... Nonetheless, where allegations are made under Articles 2 and 3 of the Convention the Court must apply a particularly thorough scrutiny... even if certain domestic proceedings and investigations have already taken place".60

In the Giuliani and Gaggio v. Italy judgment (2011), concerning the circumstances in which deprivation of life may be justified, the ECtHR emphasized: "In line with the principle of strict proportionality inherent in Article $2 \ldots$ the national legal framework must make recourse to firearms dependent on a careful assessment of the situation... Furthermore, the national law regulating policing operations

\footnotetext{
58 Ibid.

59 Judgment BabarAhmadand Others v. the United Kingdom (2012), Application nos. 24027/07, 11949/08, 36742/08, 66911/09 and 67354/09, par. 200, [http://hudoc.echr.coe.int/eng?i=001-110267], accessed 20. March 2020

60 Judgment Isayeva, Yusupova and Bazayeva v. Russia (2005), op. cit., note 28, par. 168, 169, 171, 173
} 
must secure a system of adequate and effective safeguards against arbitrariness and abuse of force and even against avoidable accident..."61

Nevertheless, in the case of Evans v. the United Kingdom (2007), it found no violation of Article 2 (right to life) and granted a state a wide margin of appreciation. Herewith, the ECtHR points out that "in the absence of any European consensus on the scientific and legal definition of the beginning of life, the issue of when the right to life begins comes within the margin of appreciation which the Court generally considers that States should enjoy in this sphere".62 Earlier in its jurisprudence the ECtHR stated that there was no consensus on the common understanding of the concept of 'moral' in Europe and "it is not only legally difficult to seek harmonisation of national laws at Community level, but because of lack of consensus, it would be inappropriate to impose one exclusive moral code".63 Accordingly, the ECtHR primarily assesses whether there is a consensus on a particular issue.

The same applies to the so-called 'right to death' and the question of whether the right to life also includes the possibility of determining the time and method of death. In this context, the ECtHR's practice is quite uniform. Namely, it emphasizes that since there is no consensus on this question, states are afforded a wide discretion. So, in the case of Lambert and Others v. France (2015), regarding the permission to withdraw the artificial life-sustaining treatment, "the Court reiterates that Article 2 ranks as one of the most fundamental provisions in the Convention, one which, in peace time, admits of no derogation under Article 15, and that it construes strictly the exceptions defined therein... However, in the context of the State's positive obligations, when addressing complex scientific, legal and ethical issues concerning in particular the beginning or the end of life, and in the absence of consensus among the member States, the Court has recognised that the latter have a certain margin of appreciation".64

A state has also a wide margin of appreciation in determining and legislative regulation at the national level of assisted suicide.65 "Comparative research shows that the majority of Member States do not allow any form of assistance to suicide...

\footnotetext{
61 Judgment Giuliani and Gaggio v. Italy (2011), op. cit., note 29, par. 209

62 Judgment Evans v. the United Kingdom (2007), Application no. 6339/05, par. 54, [http://hudoc.echr. coe.int/eng?i=001-80046], accessed 20. March 2020

63 Judgment Vo v. France (2004), Application no. 53924/00, par. 82, [http://hudoc.echr.coe.int/ eng?i=001-61887], accessed 20. March 2020

64 Judgment Lambert and Others v. France (2015), Application no. 46043/14, par. 144, [http://hudoc. echr.coe.int/eng?i=001-155352], accessed 20. March 2020

65 Judgment Haas v. Switzerland (2011), Application no. 31322/07, par. 54, 55 [http://hudoc.echr.coe. int/eng?i=001-102940], accessed 20. March 2020
} 
Only four States examined allowed medical practitioners to prescribe a lethal drug in order to enable a patient to end his or her life. It follows that the State Parties to the Convention are far from reaching a consensus in this respect, which points towards a considerable margin of appreciation enjoyed by the State in this context..."66

\subsection{Non-absolute human rights and freedoms}

When it comes to the other, non-absolute human rights and freedoms, the states usually enjoy a wide margin of appreciation, unless there is consensus on a specific issue. At the same time, the ECtHR has elaborated some criteria, factors that affect the determination of the width of the margin of appreciation, depending on the particular human right at stake.

Thereby, the margin of appreciation is wide in the sphere of social and economic rights, in determining economic well-being of a country. For example, in the James and Others $v$. the United Kingdom judgment (1986), the ECtHR found it natural that the margin of appreciation "available to the legislature in implementing social and economic policies should be a wide one".67 It stressed: "Because of their direct knowledge of their society and its needs, the national authorities are in principle better placed than the international judge to appreciate what is 'in the public interest"”.68 Thus, “... the Court will generally respect the legislature's policy choice unless it is 'manifestly without reasonable foundation".69

In the case of S.A.S. v. France (2014), concerning the blanket ban on the wearing of the full-face veil in public places, the ECtHR pointed out that regarding Art. 8 (right to respect for private and family life) and Art. 9 (freedom of thought, conscience and religion), there was no consensus in Europe as to whether or not there should be such a ban. Consequently, in search for a fair balance states enjoy a wide margin of appreciation. In the present case, the ECtHR concluded that the ban imposed by national law could be regarded as proportionate to the aim pursued, namely the preservation of the conditions of 'living together' as an element of the

\footnotetext{
66 Judgment Koch v. Germany (2012), Application no. 497/09, par. 70 [http://hudoc.echr.coe.int/ eng?i=001-112282], accessed 20. March 2020

67 Judgment James and Others v. the United Kingdom (1986), Application no. 8793/79, par. 46, [http:// hudoc.echr.coe.int/eng?i=001-57507], accessed 20. March 2020

68 Ibid., par. 46

69 Judgment Dubská and Krejzová v. the Czech Republic (2016), op. cit., note 51, par. 179
} 
'protection of the rights and freedoms of others'. So, the impugned limitation can be regarded as 'necessary in a democratic society'.70

In respect of the freedom of expression, the breadth of the margin depends on the type of speech at issue. "Whilst there is little scope under Article $10 \$ 2$ of the Convention for restrictions on political speech..., a wider margin of appreciation is generally available to the Contracting States when regulating freedom of expression in relation to matters liable to offend intimate personal convictions within the sphere of morals or, especially, religion... Similarly, States have a broad margin of appreciation in the regulation of speech in commercial matters or advertising".71

In assessing the lawfulness of the interference under Art. 10, the ECtHR analyzes such interference in the light of the case as a whole, including the form, the content and the context in which the impugned statements were made. 72 Hence, it evaluates not only the substance of the ideas and information expressed, but also the form in which they are conveyed.73

In cases of balancing the right to privacy (Art. 8) and the right to freedom of expression (Art. 10), the ECtHR reiterates that these rights deserve equal respect. Accordingly, the margin of appreciation should be the same in both situations.74 In doing so, the following relevant criteria must be taken into account: contribution to a debate of public interest; the degree of notoriety of the person affected; the subject of the news report; the prior conduct of the person concerned; the content; the form; the consequences of the publication; the circumstances in which photographs were taken; the way in which the information was obtained and its veracity; and the gravity of the penalty imposed on the journalists or publishers.75

\subsection{CONSENSUS}

It has been revealed that the presence or absence of the so-called European consensus on a particular issue significantly affects the determination of the width of the

\footnotetext{
70 Judgment S.A.S. v. France (2014), Application no. 43835/11, par. 157 - 159, [http://hudoc.echr.coe. int/eng?i=001-145466], accessed 20. March 2020

71 Judgment Mouvement raëlien suisse v. Switzerland (2012), Application no. 16354/06, par. 61, [http:// hudoc.echr.coe.int/eng?i=001-112165], accessed 20. March 2020

72 Judgment Medžlis Islamske Zajednice Brčko and Others v. Bosnia and Herzegovina (2017), Application no. 17224/11, par. 78, [http://hudoc.echr.coe.int/eng?i=001-175180], accessed 20. March 2020

73 Judgment Pentikäinen v. Finland (2015), Application no. 11882/10, par. 87, [http://hudoc.echr.coe. int/eng?i=001-158279], accessed 20. March 2020

74 Judgment Satakunnan Markkinapörssi Oy and Satamedia Oy v. Finland (2017), Application no. 931/13, par. 163, [http://hudoc.echr.coe.int/eng?i=001-175121], accessed 20. March 2020

75 Ibid., par. 165
} 
margin of appreciation granted by the ECtHR to domestic authorities. As a rule, if consensus exists, a narrow margin of appreciation will be afforded to a state, and vice versa. At the same time, in its case law the ECtHR has repeatedly emphasized that, if the case concerns sensitive moral or ethical issues, the margin will be wider. Given that human rights and freedoms should be interpreted dynamically in view of the progress of science, medicine and society, the practice of the ECtHR is also developing. In this context, an existing consensus encourages the evolution of autonomous interpretation of certain concepts by the ECtHR, such as family life, for example, that also significantly narrows a discretionary power of a state. Accordingly, the question arises of in which areas the consensus exists, and in which there is still no unified approach.

Thus, as has already been established, there is currently no consensus on the issues, such as the beginning and the end of life (in vitro fertilization, home birth,76 abortion, assisted suicide, euthanasia, etc.), the recognition of the right of an accused to defend him or herself without the assistance of a registered lawyer (Art. 6, par. 3 (c)),77 life imprisonment, 78 the concepts of moral, religion (in particular, a ban on wearing of the full-face veil in public places or the presence of religious symbols in state schools), public interest, national security, public safety, economic well-being, the pressing social need $e t$ al.

Therefore, in the case of Hämäläinen v. Finland (2014), the ECtHR did not find any consensus on allowing same-sex marriages, gender recognition and the right of transsexuals to marry.79 There is also no consensus on the second-parent adoption by same-sex couples. 80 Nevertheless, it notes that despite the lack of consensus, a clear trend is currently emerging to the introduction of different forms of legal recognition of same-sex relationships. 81

Accordingly, the ECtHR stresses that "when it comes to issues of discrimination on the grounds of sex or sexual orientation to be examined under Article 14, the

\footnotetext{
76 Judgment Dubská and Krejzová v. the Czech Republic (2016), op. cit., note 51, par. 183

77 Judgment Correia de Matos v. Portugal (2018), Application no. 56402/12, par. 137, [http://hudoc.echr. coe.int/eng?i=001-182243], accessed 20. March 2020

78 Judgment Khamtokhu and Aksenchik v. Russia (2017), Application nos. 60367/08 and 961/11, par. 85, [http://hudoc.echr.coe.int/eng?i=001-170663], accessed 20. March 2020

79 Judgment Hämäläinen v. Finland (2014), Application no. 37359/09, par. 74, [http://hudoc.echr.coe. int/eng?i=001-145768], accessed 20. March 2020

80 Judgment $X$ and Others v. Austria (2013), Application no. 19010/07, par. 147, [http://hudoc.echr.coe. int/eng?i=001-116735], accessed 20. March 2020

81 Judgment Vallianatos and Others v. Greece (2013), Application nos. 29381/09 and 32684/09, par. 91, [http://hudoc.echr.coe.int/eng?i=001-128294], accessed 20. March 2020
} 
State's margin of appreciation is narrow".82 It further emphasizes that "the advancement of gender equality is today a major goal in the member States of the Council of Europe and very weighty reasons would have to be put forward before such a difference of treatment could be regarded as compatible with the Convention... In particular, references to traditions, general assumptions or prevailing social attitudes in a particular country are insufficient justification for a difference in treatment on grounds of sex. For example, States are prevented from imposing traditions that derive from the man's primordial role and the woman's secondary role in the family..."83

Regarding the freedom of expression, there is no consensus, inter alia, on how to regulate paid political advertising in broadcasting. This lack of consensus also broadens the margin of appreciation over the restrictions on public interest expression. 84 However, the ECtHR confirms the consensus on the need to recognize an individual right of access to state-held information in order to enable the public to "scrutinize and form an opinion on any matters of public interest, including on the manner of functioning of public authorities in a democratic society", that is an integral part of the freedom of expression.85 In addition, it highlights that "the Internet has now become one of the principal means by which individuals exercise their right to freedom to receive and impart information and ideas, providing as it does essential tools for participation in activities and discussions concerning political issues and issues of general interest..."86

On the other hand, consensus exists on the definition of concepts, such as torture, inhuman or degrading treatment or punishment, the law, rule of law,87 private and family life, home, data protection. There is also a 'virtually general consensus' on the recognition in the majority of national legislations and practice the right to conscientious objection. 88

82 Judgment $X$ and Others v. Austria (2013), op. cit., note 80, par. 148

83 Judgment Konstantin Markin v. Russia (2012), Application no. 30078/06, par. 127, [http://hudoc. echr.coe.int/eng?i=001-109868], accessed 20. March 2020

84 Judgment Animal Defenders International v. the United Kingdom (2013), Application no. 48876/08, par. 123, [http://hudoc.echr.coe.int/eng?i=001-119244], accessed 20. March 2020

85 Judgment Magyar Helsinki Bizottság v. Hungary (2016), Application no. 18030/11, par. 139, [http:// hudoc.echr.coe.int/eng?i=001-167828], accessed 20. March 2020

86 Judgment Cengiz and Others v. Turkey (2016), Application nos. 48226/10 and 14027/11, par. 49, [http://hudoc.echr.coe.int/eng?i=001-159188], accessed 20. March 2020

87 Nußberger, A., The European Court of Human Rights and rule of law - a tale of hopes and disillusions, in: Zubik, M. (ed.), Human rights in contemporary world: Essays in Honour of Professor Leszek Garlicki, Wydawnictwo Sejmowe, Warszawa, 2017, pp. 162 - 173

88 Judgment Bayatyan v. Armenia (2011), Application no. 23459/03, par. 103, 108, [http://hudoc.echr. coe.int/eng?i=001-105611], accessed 20. March 2020 
In the judgment of $A, B$ and $C v$. Ireland (2010), the ECtHR states, that the notion of 'private life' within the meaning of Art. 8 is a broad concept which encompasses, prima facie, the right to personal autonomy and personal development. It concerns such subjects, as gender identification, sexual orientation and sexual life, a person's physical and psychological integrity, as well as decisions both to have and not to have a child or to become genetic parents. 89

The concept of 'private life' is initially understood as the right to privacy, that is the right to live, as far as one wishes, protected from publicity or the right to live privately, away from unwanted attention. It protects the right to personal development (in terms of personality or personal autonomy) and encompasses the right for each individual to establish and develop relationships with other people and with the outside world, - the right to a 'private social life' that may also include professional activities or activities taking place in a public context.90

Moreover, the ECtHR reiterates that the concept of 'private life' is not susceptible to exhaustive definition and "covers the physical and psychological integrity of a person and can therefore embrace multiple aspects of a person's identity, such as gender identification and sexual orientation, name or elements relating to a person's right to their image. The concept covers personal information which individuals can legitimately expect should not be published without their consent... "91 Therefore, "the protection of personal data is of fundamental importance to a person's enjoyment of his or her right to respect for private and family life, as guaranteed by Article 8 of the Convention. ... Article 8 of the Convention thus provides for the right to a form of informational self-determination, allowing individuals to rely on their right to privacy as regards data which, albeit neutral, are collected, processed and disseminated collectively and in such a form or manner that their Article 8 rights may be engaged".92

However, "an attack on a person's reputation must attain a certain level of seriousness and in a manner causing prejudice to personal enjoyment of the right to respect for private life. Moreover, Article 8 cannot be relied on in order to complain

89 Judgment $A, B$ and $C$ v. Ireland (2010), Application no. 25579/05, par. 212, [http://hudoc.echr.coe. int/eng?i=001-102332], accessed 20. March 2020

90 Judgment National Federation of Sportspersons' Associations and Unions (FNASS) and Others v. France (2018), op. cit., note 36, par. 152, 153

91 Judgment M.L. and W.W. v. Germany (2018), Application nos. 60798/10 and 65599/10, par. 86, [http://hudoc.echr.coe.int/eng?i=001-183947], accessed 20. March 2020

92 Judgment Satakunnan Markkinapörssi Oy and Satamedia Oy v. Finland (2017), Application no. 931/13, par. 137, [http://hudoc.echr.coe.int/eng?i=001-175121], accessed 20. March 2020 
of a loss of reputation which is the foreseeable consequence of one's own actions such as, for example, the commission of a criminal offence..."93

The ECtHR has also emphasized that the Internet as a special source of information differs from the print media, especially regarding its capacity to store and transmit information. Hence, the risk of harm posed by the content and communications on the Internet to the enjoyment of human rights and freedoms, particularly the right to respect for private life, is significantly higher than the risk posed by the press, particularly due to the importance of search engines. $94 \mathrm{Nev}-$ ertheless, the ECtHR underlines that "the balancing of the interests at stake may result in different outcomes depending on whether a request for deletion concerns the original publisher of the information, whose activity is generally at the heart of what freedom of expression is intended to protect, or a search engine whose main interest is not in publishing the initial information about the person concerned, but in particular in facilitating identification of any available information on that person and establishing a profile of him or her".95

At the same time, the ECtHR maintains that the legislation regulating the interruption of pregnancy touches upon the sphere of the private life of a woman "cannot be interpreted as meaning that pregnancy and its termination pertain uniquely to the woman's private life as, whenever a woman is pregnant, her private life becomes closely connected with the developing foetus. The woman's right to respect for her private life must be weighed against other competing rights and freedoms invoked including those of the unborn child".96

The ECtHR also considered that there was a consensus amongst a substantial majority of the member states of the Council of Europe towards allowing abortion on broader grounds than accorded under Irish law.97 However, it "does not consider that this consensus decisively narrows the broad margin of appreciation of the State. ...this consensus cannot be a decisive factor in the Court's examination of whether the impugned prohibition on abortion in Ireland for health and wellbeing reasons struck a fair balance between the conflicting rights and interests, notwithstanding an evolutive interpretation of the Convention".98

\footnotetext{
93 Judgment M.L. and W.W. v. Germany (2018), op. cit., note 91, par. 88

$94 \quad$ Ibid., par. 91

95 Ibid., par. 97

96 Judgment $A, B$ and $C$ v. Ireland (2010), op. cit., note 89, par. 213

$97 \quad$ Ibid., par. 235

$98 \quad$ Ibid., par. 236, 237
} 
The concept of 'home' in the context of Art. 8 is an autonomous one, which does not depend on classification under national law, but is defined by reference to the factual circumstances, namely the 'existence of sufficient and continuous links with a specific place'. In this sense, a home is the place, the physically defined area, where private and family life develops. On this basis, an individual has a right to respect for his home that includes not only the right to the actual physical area, but also the quiet enjoyment of that area. In particular, it is protected from concrete or physical breaches, such as unauthorized entry into a person's home. In addition, the notion of 'home' may be equally applied to a holiday home. As for an artist's dressing room or a hotel room, the ECtHR has not ruled out that they may be considered as a 'home'. Nevertheless, the concept of home is not confined to places of residence where private life is conducted. Consequently, it encompasses professional premises as well, that is especially important for the protection of individuals against arbitrary interference by public authorities.99

Regarding the notion of 'family life' in Art. 8, the ECtHR stresses that it encompasses not only families based on marriage, but also other de facto relationships. Thus, attention must be drawn to such relevant factors, as whether the couple live together, the length of their relationship and whether they have demonstrated their commitment to each other by having children together or by any other means.100

Concerning the family life of a child, the ECtHR "reiterates that there is a broad consensus, including in international law, in support of the idea that in all decisions concerning children, their best interests are of paramount importance..."101 In the process of balancing between the interests of parents and the interests of a child "a particular importance should be attached to the best interests of the child which, depending on their nature and seriousness, may override those of the parents..."102 On the other side, "when a considerable period of time has passed since the child was originally taken into public care, the interest of a child not to have his or her de facto family situation changed again may override the interests of the parents to have their family reunited" 103.

\footnotetext{
99 Judgment National Federation of Sportspersons' Associations and Unions (FNASS) and Others v. France (2018), op. cit., note 36, par. 154

100 Judgment $X, Y$ and $Z v$. the United Kingdom (1997), Application no. 21830/9336, par. 36, [http:// hudoc.echr.coe.int/eng?i=001-58032], accessed 20. March 2020

101 Judgment Strand Lobben and Others v. Norway (2019), Application no. 37283/13, par. 204, 206, [http://hudoc.echr.coe.int/eng?i=001-195909], accessed 20. March 2020

102 Ibid., par. 208

103 Ibid.
} 
With regard to the manner in which the social relationship between a child conceived by artificial insemination by donor and the person who performed the role of father should be reflected in law, the ECtHR didn't observe the existing consensus. In particular, there was no consensus on the matter whether the interests of a child were best served by preserving the anonymity of the donor of the sperm or whether the child should have the right to know the donor's identity. 104

\section{CONCLUSIONS}

Under the principle of proportionality each legal interference with human rights and freedoms must meet the following criteria: relevancy - the appropriateness of the means intended to achieve legal aim to the purpose (the use of prohibited means, such as torture, is banned; assessment of the legitimacy of the purpose of the mean must be derived from the constitution and the laws; proper validity of appropriate mean and its necessity to achieve the goal, - substantive rationality); necessity - the use of such mean that least restricts the right of the individual; proportionality in the narrow sense: the proportionality of a person's loss (harm) from the restriction of the right to the benefit gained from the goal pursued, - the principle of balancing (procedural rationality).

The permissible limitations on human rights must be prescribed by the law and be necessary in a democratic society. The quality of the law requires it to be accessible and foreseeable. The concept of the law (in its substantive sense) may encompass the secondary and unwritten law.

In turn, the concept of democratic society refers to its basic elements, such as pluralism, tolerance and broadmindedness. In order to strike a fair balance, the ECtHR applies strict (in respect of absolute rights) and persuasive (convincing) democratic necessity tests.

Under the strict necessity test, any interference with human rights must be strictly proportionate to the achievement of the permitted aims. In this regard, the states generally enjoy a narrow margin of appreciation.

The convincing test on necessity requires the establishment of the existence of a real pressing social need as well as relevant and sufficient reasons for the interference with human rights and freedoms that must be convincingly shown by domestic authorities. Therefore, the margin afforded is wider.

104 Judgment S.H. and Others v. Austria (2011), Application no. 57813/00, par. 83, [http://hudoc.echr. coe.int/eng?i=001-107325], accessed 20. March 2020 
The scope and the width of the margin of appreciation depends on the nature of the right in issue, its importance for the individual, and the nature of the aim pursued by the restrictions.

In case of positive obligations of a state, it would rather have a wide margin of appreciation. When it comes to negative obligations, a margin is quite narrow. It also concerns the interpretation by domestic authorities of such ambiguous concepts, as national security, public safety, economic well-being, morality, democracy et $a l$. On the one hand, it is justified by the principle of non-interference in state sovereignty (based on the demand for pluralism in a democratic society) and, on the other, by the lack of consensus among the Council of Europe member states on some morally and ethically sensitive issues.

Therefore, the presence of the European consensus on a particular issue plays a key role in assessing the margin of appreciation. If consensus exists, the margin is narrow. If the issue concerns complex moral or ethical questions on which there is no consensus, the margin is wide.

The evolution of consensus contributes to the development of dynamic interpretation of human rights, as well as autonomous concepts elaborated in the case law of the ECtHR. These concepts (e.g., private and family life, home, rule of law, the law, torture, data protection, etc.) significantly narrow the margin of free discretion of a state.

\section{REFERENCES}

\section{BOOKS AND ARTICLES}

1. Alexy, R., Constitutional Rights, Balancing and Rationality, Ratio Juris, vol. 16, 2003, pp. $131-140$

2. Alexy, R., Formal principles: Some replies to critics, International Journal of Constitutional Law, vol. 12, issue 3, 2014, pp. $511-524$

3. Gerards, J., How to improve the necessity test of the European Court of Human Rights, International Journal of Constitutional Law, vol. 11, issue 2, 2013, pp. 466 - 490

4. Greer, S., The exceptions to Articles 8 to 11 of the European Convention on Human Rights, Council of Europe Publishing, Strasbourg, 1997

5. Huber, P., M., The principle of Proportionality, in: Schroeder, W. (ed.), Strengthening the rule of law in Europe: from a common concept to mechanisms of implementation, Hart Publishing, Oxford and Portland, Oregon, 2016, pp. $98-112$

6. Huscroft, G., Proportionality and the Relevance of Interpretation, in: Huscroft, G.; Miller, B. W.; Webber, G. (eds.), Proportionality and the rule of law: Rights, Justification, Reasoning, Cambridge University Press, New York, 2014, pp. $186-202$ 
7. McGoldrick, D., A defence of the margin of appreciation and an argument for its application by the Human Rights Committee, International and Comparative Law Quarterly, vol. 65, issue 1, 2016, pp. $21-60$

8. Möller, K., Proportionality: Challenging the critics, International Journal of Constitutional Law, vol. 10, issue 3, 2012, pp. $709-731$

9. Nußberger, A., The European Court of Human Rights and rule of law - a tale of hopes and disillusions, in: Zubik, M. (ed.), Human rights in contemporary world: Essays in Honour of Professor Leszek Garlicki, Wydawnictwo Sejmowe, Warszawa, 2017, pp. 162 - 173

10. Popelier, P.; Van De Heyning, C., Procedural rationality: giving teeth to the proportionality analysis, European Constitutional Law Review, No. 9 (2), 2013, pp. 230 - 262

11. Spielmann, D., Allowing the Right Margin the European Court of Human Rights and the National Margin of Appreciation Doctrine: Waiver or Subsidiarity of European Review?, Cambridge Yearbook of European Legal Studies, vol. 14, 2012, pp. 381 - 418

\section{ECHR}

1. European Convention for the Protection of Human Rights and Fundamental Freedoms, as amended by Protocols Nos. 11 and 14, 4 November 1950, ETS 5

2. Handyside v. the United Kingdom (1976), No. 5493/72

3. The Sunday Times $v$, the United Kingdom (1979), No. 6538/74

4. Silver and Others $v$. the United Kingdom (1983), No. 5947/72; 6205/73; 7052/75; 7061/75; 7107/75; 7113/75; 7136/75

5. Malone v. the United Kingdom (1984), No. 8691/79

6. James and Others $v$. the United Kingdom (1986), No. 8793/79

7. Groppera Radio AG and Others v. Switzerland (1990), No. 10890/84

8. Huvig v. France (1990), No. 11105/84

9. Kruslin v. France (1990), No. 11801/85

10. The Sunday Times $v$. the United Kingdom (no. 2) (1991), No. 13166/87

11. Observer and Guardian v. the United Kingdom (1991), No. 13585/88

12. McCann and Others v. the United Kingdom (1995), No. 18984/91

13. $X, Y$ and $Z v$. the United Kingdom (1997), No. 21830/9336

14. Chapman v. the United Kingdom (2001), No. 27238/95

15. Prince Hans-Adam II of Liechtenstein v. Germany (2001), No. 42527/98

16. Hatton and Others v. the United Kingdom [GC] (2003), No. 36022/97

17. Gorzelik and Others v. Poland (2004), No. 44158/98

18. Vo v. France (2004), No. 53924/00

19. Isayeva, Yusupova and Bazayeva v. Russia (2005), Nos. 57947/00, 57948/00 and 57949/00

20. Evans v. the United Kingdom (2007), No. 6339/05

21. A, B and Cv. Ireland (2010), No. 25579/05

22. Giuliani and Gaggio v. Italy (2011), No 23458/02 
23. Bayatyan v. Armenia (2011), No. 23459/03

24. Haas v. Switzerland (2011), No. 31322/07

25. S.H. and Others v. Austria (2011), No. 57813/00

26. Koch v. Germany (2012), No. 497/09

27. Mouvement raëlien suisse v. Switzerland (2012), No. 16354/06

28. Finogenov and Others v. Russia (2012), Nos. $18299 / 03$ and 27311/03

29. Babar Ahmad and Others v. the United Kingdom (2012), Nos. 24027/07, 11949/08, 36742/08, 66911/09 and 67354/09

30. Konstantin Markin v. Russia (2012), No. 30078/06

31. X and Others v. Austria (2013), No. 19010/07

32. Vallianatos and Others v. Greece (2013), Nos. 29381/09 and 32684/09

33. Animal Defenders International v. the United Kingdom (2013), No. 48876/08

34. National Union of Rail, Maritime and Transport Workers v. the United Kingdom (2014), No. $31045 / 10$

35. O'Keeffe v. Ireland (2014), No. 35810/09

36. Hämäläinen v. Finland (2014), No. 37359/09

37. S.A.S. v. France (2014), No. 43835/11

38. Trabelsi v. Belgium (2015), No. 140/10

39. Pentikäinen v. Finland (2015), No. 11882/10

40. Lambert and Others v. France (2015), No. 46043/14

41. Kavaklıoğlu and Others v. Turkey (2016), No. 15397/02

42. Magyar Helsinki Bizottság v. Hungary (2016), No. 18030/11

43. Dubska and Krejzová v. the Czech Republic (2016), Nos. 28859/11 and 28473/12

44. Cengiz and Others v. Turkey (2016), Nos. 48226/10 and 14027/11

45. Satakunnan Markkinapörssi Oy and Satamedia Oy v. Finland (2017), No. 931/13

46. Medžlis Islamske Zajednice Brčko and Others v. Bosnia and Herzegovina (2017), No. 17224/11

47. Khamtokhu and Aksenchik v. Russia (2017), Nos. 60367/08 and 961/11

48. National Federation of Sportspersons' Associations and Unions (FNASS) and Others v. France (2018), Nos. 48151/11 and 77769/13

49. Correia de Matos v. Portugal (2018), No. 56402/12

50. M.L. and W.W. v. Germany (2018), Nos. 60798/10 and 65599/10

51. Strand Lobben and Others v. Norway (2019), No. 37283/13 